\title{
Illegal Hunting Prevention by Indigenous People in Bromo Tengger Semeru National Park
}

Hablana Rizka Achmadi ${ }^{1}$, Adelia Ramadhani Savitri², Adhe Puspawari Hardhany ${ }^{3}$, Ayu Rini Tirtasari Haryono ${ }^{4}$, Muh. Danny Wirawan ${ }^{5}$

1. Notarial Law Program, Faculty of Law, Universitas Airlangga, Surabaya, harizkkaachmadi28@gmail.com

2. Notarial Law Program, Faculty of Law, Universitas Airlangga, Surabaya, adeliarsav@gmail.com

3. Notarial Law Program, Faculty of Law, Universitas Airlangga, Surabaya, ahardhany@gmail.com

4. Notarial Law Program, Faculty of Law, Universitas Airlangga, Surabaya, ayurinitirtasari@gmail.com

5. Notarial Law Program, Faculty of Law, Universitas Airlangga, Surabaya, muh.danny$\underline{12 @ g m a i l . c o m}$

Abstract

Introduction to The Problem: National park is a conservation area which has the most advanced management system compared to forest park, Nature Park, nature reserves, and wildlife reserves. The national park is becoming the area that can anticipate the hunt and to prevent the extinction of protected animals. One of the largest national parks in East Java is Bromo Tengger Semeru. Around the park, there lived a Tengger tribe whose role is to maintain the conservation areas.

Purpose/Objective Study: The purpose is to determine the response on illegal hunting conducted by people around Bromo Tengger Semeru National Park and to determine the factors supporting the illegal hunting prevention in Bromo Tengger Semeru National Park.

Design/Methodology/Approach: The type of this study is sociological law study using qualitative methodology — the data collected through observation, interviews, and literature.

Findings: The results show that the way the Tengger tribe prevent illegal hunting is by doing spiritual guidance. While the supporting factors in preventing illegal hunting is the law and legal custom owned by Tengger tribe, thus the customary law applied by Tengger tribe is more effective than national law.

Paper Type: Research Article

Keywords: Illegal hunting; Prevention; Indigenous people

\section{Introduction}

Biological resources and ecosystem are the elements in forming a living environment and having a function to balance the existed ecosystem. The diversity of plants and animals within the forest is the gift given by God, which needed to be maintained and protected with the life support system, preservation, and sustainable use of biological resources and its ecosystem. Forest protection is a part of an activity done to secure 
the forest area, resources, and its environment due to achieve sustainable and optimal biosphere.

The formed ecosystem has an essential role in human life; hence, the conservation effort on the biological resource and its ecosystem become the duty for every generation. One of the elements is animal. There are many wild animals which exploited by a human, such as a buffalo, deer, antelope, mouse deer, pangolin, snake, monitor lizard, gecko, white-rumped shama, black-napped oriole, oriental magpierobin, peacock, starling, dolphin, shark, and others. Illegal animal hunting will then lead to the extinction and instability of the ecosystem. The survival of these animals needs protection for keeping future ecosystem stability.

Based on the ProFauna (Protection of Forest and Fauna) record, an increase on the total cases of animal hunting in East Java was occurred in 2015 with 370 cases, while in 2014 the illegal animal hunting was less than 100 cases. The animals listed on local extinction are, such as jungle cats, Javan langurs, Javan eagles, and Javan slow lorises (Lumajang, 2016). Moreover, in 2019, some wild animals were found in East Java. For instance, a black langur found around Zainul Hasan Islamic Institute Ponorogo on February $4^{\text {th }}, 2019$. The security claimed they often saw the Javan langur hang on the tree (ProFauna, 2019b). Besides, the Large Conservation Center for Natural Resources in East Java had succeeded getting two animals - Moluccan cockatoo and Black-capped lorry which captured by Lesanpuro citizen, Malang on March 8th, 2019. It showed that illegal animal hunting traded by society was still rampant (ProFauna, 2019a). Most of the illegal hunt, unfortunately, happened around the conservation area that should become the safest area for protected animals.

In Indonesia, National Park has become one of the conservation areas that relatively advance in its construction and management systems compared to Forest Park, Nature Park, Nature Reserve, and Wildlife Reserves. Even, it gets serious attention in its development due to its capability to protect the extinction of animals and plants. One of them is Bromo Tengger Semeru, National Park.

Bromo Tengger Semeru National Park is a conservation area located in East Java. This National Park has assigned as a Technical Implementation Unit based on the Ministry of Forestry decree No. 178/MENHUTII/2005 by the Directorate General of Natural Resources Conservation and Ecosystem (Balai Besar Taman Nasional Bromo Tengger Semeru in Sawitri \& Takandjandji, 2019). It has around 137 birds, 22 mammals and 4 reptiles, including Asian palm civet (Paradoxurus Hermaphroditus), Javan deer (Cervus Timorensis), long-tailed macaque (Macaca Fascicularis), barking deer (Muntiacus Muntjak), red junglefowl (Gallus Gallus), leopard (Panthera Pardus), dhole (Cuon Alpinus), and some birds such as besra sparrowhawk (accipiter virgatus), rhinoceros hornbill (Buceros Rhinoceros Silvestris), crested serpent eagle (spilornis cheela bido), black drongo (Dicrurus Macrocercus), instability kite (Haliastur Indus), 
and whistling duck that lived in Ranu Pani, Ranu Regulo, and Ranu Kumbolo (Suheriyanto, 2012).

Apart from being a tourism spot, Bromo Tengger Semeru National Park also has cultural values since the society around the Park had a role in securing the conservation area. Most of the society that lives around Bromo Mountain is Tengger tribe. In their daily activity, they regulate the behavior and attitude as customary provisions, which functioned as a social control system within the community. Custom law is a community law which born from the culture tales by tales. One of the rules that must be obeyed by Tengger tribe is prohibition in hurting or killing the animal (except for sacrifice) (Aziz, 2011). This custom law has a purpose in defending the environment sustainability around Bromo Tengger area. However, there has been widespread on hunting cases around Bromo Tengger Semeru National Park.

Based on the data of the Supreme Court verdict, there are two animals hunters caught by policemen. They were the residents from Lumajang near Bromo Tengger Semeru area. Both hunters were caught having tool for catching bird, including 2 pieces of green palm fiber net with $5 \mathrm{~m}$ long and $1.5 \mathrm{~m}$ wide, 1 piece of wooden cage, 2 pieces of small white plastic, 2 sickle blades, 4 white pipes and $3 \mathrm{~m}$ long of brown rope (Mahkamah Agung, 2013). Another hunter was from Malang who caught by the forest guard officer along with the evidence, such as air rifle, a chestnut capped thrush, an orange-spotted bulbul, and two dead Sunda minivet (Mahkamah Agung, 2013).

Based on the cases above, the researchers are interested in examining the application of custom law in handling the illegal hunting around Bromo Tengger Semeru National Park. Since Tengger society had their owned custom law that has been implemented in generations to support the environment and ecosystems preservation, thus this study aims to know the prevention on illegal animal hunting by people around Bromo Tengger Semeru National Park. Also, the supporting factors in preventing illegal hunting.

\section{Methodology}

This study used qualitative methodology to describe legal prevention done by Tengger tribe society against illegal animal hunting around Bromo Tengger Semeru National Park. The research used sociological law as the research type, and it combined two legal elements; that is, normative law which has written inside the law regulation and law as a norm that considered appropriate for people guidance (Amiruddin \& Asikin, 2006). This sociological law was done to know how custom law is applied, including the process in preventing the protected animals hunting.

The research object is to observe the custom law applied by Tengger tribe society in maintaining the conservation of Bromo Tengger Semeru National Park. The data obtained from interviewing people around Bromo Tengger Semeru, including Tengger tribe, and library search. 
Triangulation was used as the data analysis technique to guarantee accurate data based on the field. Triangulation was the best technique to eliminate the differences in reality construction within the context of a study while collecting data on the various phenomenon and related view (Moleong, 2017).

\section{Result and Discussion}

\section{Prevention on Protected Animals Hunting}

The existence of custom society recognized by a Country if it fulfills the requirements as written on article 18B paragraph (2) of the 1945 Constitution, Supreme Court Verdict No. 31/PUU-V/2007 and No. 35/PUU-X/2012. The first requirement is that an indigenous entity is the aggregation of indigenous whose existence stand since the ancestor period, and they managed to defend its unity without interruption. Second is having in-group feeling and having custom regulation as its third. Fourth is having assets or shared objects. The fifth is having customary norms. Sixth is a particular area for territorial indigenous. Seventh is that the substance of traditional rights are recognized and respected by both indigenous and other people, and not contradictory with humans' right. Ninth is not threatening the sovereignty and integrity of the Republic of Indonesia. The tenth is that the customary norms are suitable and not contradictory with constitution regulations. The last requirement is the existence of indigenous along with their traditional rights (Kurniawan et al., cited in Salam, 2016). Those requirements have drawn in Tengger tribe society. Tengger tribe society had a prevailing customary law that transparent to era development. They adhere to State law since the customary law and state law are inline together. Even though Tengger customary law is not a written law, but if somebody is opposed the law, then the sanctions will be imposed according to the customary law.

The legal function within society is to guarantee the safety and the accomplishment of social structure. Legal, along with religion, morality, customary, education, culture, and leader standard is the means to control social behavior. Similar to the Tengger tribe who makes customary law as the social control system.

The first customary law expert in Indonesia, Soepomo (cited in Sukirno, 2018), said that custom law is a regulation on humans' attitude within the society. It is a form of life which its citizen live together for a long time hence creates a culture (Sukirno, 2018). Another customary law expert, Djojodigoeno, stated that customary law is a chain of paugeran (norms) that developed and maintained the social relationship (Sukirno, 2018). Djojodigoeno also claimed that customary law sees society as a community that respects each other. Therefore, most of the legal settlement is done with peace and not based on right or wrong (Sulastriyono \& Pradhani, 2018). There are normative rules, pieces of advice in the form of a proverb, and unwritten law principles that manage the life of indigenous people. Even though it is the unwritten law principles, but the sanction for normative infringement still exists. 
Based on the interview, the sanction applied by Tengger society tends to be preventive. Since the Tengger tribe society is very dense with Magis religious belief, they believe that every action will get reward and punishment from God. They used the moralistic methodology in preventing illegal animal hunting. The hunter will be adviced and educated with spiritual mental to become a better person, such as raising a horse, cleaning worship place, purging the perpetrator, even announcing the perpetrator in public. This is in accordance with Negara who stated that giving advice to Tengger society is useful due to their belief in Sesanti Pancasetia (five forms of fidelity), namely; setya budaya (obedience and respect the tradition), setya wacana (word and action are synchronize), setya semaya (keeping promises), setya laksana (responsible), and setya mitra (building solidarity). Therefore, Tengger society can accept advice from all parties (Negara, 2018).

Meanwhile, if the perpetrator is not coming from Tengger society, the government will officially solve it through the state legal procedure. The State of law on animal hunting regulated in 1945 Constitution No. 5 of 1990 on the Conservation of Biological Resource and Ecosystem. This Constitution prescribed the criminal provision for the illegal animal hunter. The Article 40 of the 1945 Constitution No. 5 of 1990, "those who deliberately do infringement on the provision as written in article 19 paragraph (1) and Article 33 paragraph (1), convicted with imprisonment for 10 (ten) years long and paying fine for Rp. 200.000.000,00 (two hundred million rupiahs)."

There are some stages to prevent animal hunting. The first step is advising the hunter about the importance of preserving the ecosystem sustainability. The advice more likely accepted by the Tengger tribe because they are aware of the prohibition of torturing and killing animals. Another step is prevention through the chieftain authority. The tribe's chieftain has responsible for his authority to organize general government affairs; hence, he provided guidance and discipline in the village. He also can collaborate with Bromo Tengger Semeru National Park party. The prevention also is done by regional police when the prevention by chieftain is unworking. At this stage, the prevention will likely enter into the criminal law sector. However, the law enforcement which done through State law is still having obstacles, such as the government or law enforcer is not assertive in handling the case. There is no specific regulation that regulates on animal protection, and the lack of people awareness in which they have not yet implement the existed legal rule (Liuw, 2015).

Therefore, the attempt to prevent illegal hunting by Tengger tribe society emphasizes more into awakening Tengger tribe society and people awareness. Thus, usually, the cases will be solved through discussion that attended by chieftain, perpetrator, and people who involved in the case, rather than giving the case to be solved by a police officer. Hence, prevention is more optimal due to their firm belief.

\section{The Supporting factors in Hunting Protected Animals}


Theoretically, the efforts to prevent crime divided into two efforts. The first effort is in the form of a criminal or repressive law, and the second is non-criminal or preventive law. The severe punishment seems not optimally overcome the crime. The things that should be considered to be important is the cause of crime itself. Hence, to prevent the hunting of wild animals, the perpetrator must not be subjected to criminal law. The preventive law can be a little step to prevent the crime of protected animals hunting. The prevention of protected animals hunting in Tengger society can be given merely by providing a suggestion on the importance of keeping the ecosystem sustainability. For the indigenous Tengger people, it is understandable since they know that hurting or even killing animals is wrongdoing (wewaton, in the Javanese Language).

Tengger tribe is still holding onto ecology wisdom's values. These values become cultural strength which having environment structure about the proper relationship between human and its environment. The ecology wisdom's values owned by Tengger society is in line with the research conducted by Yesika Liuw. The research stated that animals prosecution happened due to the human perspective that view animal as a merely ordinary being; however, animals are God's creation as well (Liuw, 2015). The changing in ecosystem both naturally and uncontrolled human influence can be a threat to animals, especially endangered animals.

The establishment of Bromo-Tengger district as National Park means that the existing condition will be protected more and developed to be unique. Tengger, as foundation district, also means that their cultures should be protected and developed to be perfect, especially the customs and the cultural values. Also, it should not contradict with Pancasila values as state's philosophy (Aziz, 2011). Tengger society is still honoring the equality values, democracy, society life, and spiritual leader as like shaman since Tengger society having their law besides the formal law in Indonesia. For Tengger society, the Tengger law customs has able to regulate and control any various problems in society. The society believes that law customs is representation from Tengger society norms manifested in their interaction with human or environment. The law consists of prohibition in killing or hurting animals except for sacrificing and eating, a prohibition to doing the crime, a prohibition to lie, and prohibition to drunk (Nurcahyono \& Astutik, 2018). Tengger society believes in which if they disturb the law customs; then they will get karma such as prolonged illness, bad fortune, and decrease in the agricultural product (Cahyani \& Maftuhah, 2018).

Based on interview results, law customs that have been obtained by Tengger society is more effective than national law since society is more obeying the Tengger law customs. They tend to the Tengger law because they do believe in karma reward in which the human fate is determined by the reward. Sukari and his colleagues, as quoted by Nurcahyono and Astutik, explain that Tengger society believes in three concepts: 1) Tri Sandya concepts (pray three times a day); 2) reward karma (life or human fate depends on rewards); 3 ) the born of tumimbal law concepts (the must 
obeyed living law). Another concept that is believed by Tengger society is life environment viewed as sources of life (sumbere panguripan) which regulate the relationship between society and the environment (Nurcahyono \& Astutik, 2018). Hence, the relation between Tengger society with National Park will be more enclosed since Bromo-Tengger-Semeru mostly inhabited by Tengger society. If the nature condition will be developed into National Park, then the society around is hoping to be able to save, maintain, and develop the ecosystem.

As written by Haliim in his research, the active empowerment of Bromo Tengger Semeru National Park will involve the Tengger society itself in planning, implementation, advantageous taking, observing and management evaluation toward the national park itself (Haliim, 2018). He also adds that empowerment which involving Tengger society is relatively easy because the pandhita as social institution commands Tengger society (Haliim, 2018). In the other side, if Tengger society does not have the chance to get advantageous from National Park, then the possibility is their uncaring on maintaining the environment. For the sake of National Park sustainability, Tengger society is hoped to have owned feeling (handarbeni), maintaining (hamengkoni), and taking benefit from it (Aziz, 2011).

Based on the theory and research's result, it shows that Tengger society is supporting the natural environment sustainability. The factors that were supporting the protected animals' prevention are law regulation and law culture. Tengger society has an institutional structure, namely religious leader institutional and shaman custom institutional. The shaman custom institutional has to observe the implementation of customs regulation and law customs. Then, the shaman custom institutional consists of shaman assistance custom and former leader. By the existence of Shaman custom institution, hence there will be good coordination with conservation institutional to maintain the natural environment. Tengger society is still own their ecology wisdom values; thus, Tengger society uses law customs as the social control system. Afterward, through the family manner will then prevent the illegal hunting of protected animals'. Also, the punishment given to the perpetrator tends to make the perpetrator realized their crime, so therefore, law custom in Tengger is more effective than national law.

\section{Conclusion}

According to the result of analysis and discussion that has conducted, it concludes that Tengger societies' prevention toward protected animals hunting performed through the moralistic method. The moralistic method is prevention method that applied due to the existing law custom in Tengger (religious magic). Afterward, the following steps in preventing the hunting of protected animals are. Firstly, prevention through the authority of pandhita shaman (ki petinggi). Secondly, if the prevention is unresolved yet, then the prevention will be conducted by the village head. Third, after the two efforts, the police will act to prevent it. In the prevention of protected animals hunting, Tengger society has implemented its local regulation; the society which involves 
Jurnal Hukum

Novelty

Volume 10, Issue 01, 2019, pp. 65-73

P-ISSN: $1412-6834$

E-ISSN: 2550-0090

hunting will be shown up through forum discussion. This effort is considered to be more optimal in hunting prevention due to existing beliefs and culture.

\section{Reference}

Amiruddin, M., \& Asikin, Z. (2006). Pengantar Metode Penelitian Hukum. Jakarta: Raja Grafindo Persada.

Aziz, N. M. (2011). Laporan Akhir Tim Pemantauan Dan Inventarisasi Perkembangan Hukum Adat Badan Pembinaan Hukum Nasional. In Kementerian Hukum Dan Hak Asasi Manusia RI Badan Pembinaan Hukum Nasional. https://doi.org/10.1017/CB09781107415324.004

Cahyani, D., \& Maftuhah, A. (2018). Perempuan Dititik Lima Derajat Celcius: Fenomenologi Relasi Gender Masyarakat Suku Tengger Argosari. An-Nisa', Vol.11(No.2), 197-206.

Haliim, W. (2018). Dinamika Implementasi Kebijakan Konservasi Lahan Taman Nasional Bromo Tengger Semeru. Jurnal Borneo Administrator. https://doi.org/10.24258/jba.v14i1.327

Liuw, Y. (2015). Perlindungan Hukum Terhadap Hewan Lindung Menurut Undangundang Nomor 5 Tahun 1990. Lex Crimen, 4(3).

Lumajang, L. S. F. (2016). Selama 2015, 370 Kasus Perburuan Satwa Liar dilindungi di Jatim. Retrieved November 11, 2015, from Suara Surabaya website: http://www.suarasurabaya.net/jaringradio/news/2016/ 165522-Selama2015,-370-Kasus-Perburuan-Satwa-Liar-Dilindungi-di-Jatim

Mahkamah Agung. (2013). Direktori Putusan Mahkamah Agung Indonesia. Retrieved November 11, 2015, from https://putusan.mahkamahagung.go.id/putusan/downloadpdf/3ee4b108dc48 b989c811543e51b5fdeb/pdf

Moleong, L. J. (2017). Metodologi Penelitian Kualitatif (Edisi Revisi). In PT. Remaja Rosda Karya.

Negara, P. D. (2018). Budaya Malu Pada Masyarakat Tengger dan Pengaruhnya terhadap Budaya Hukum Penghindaran Konflik. Widya Yuridika. https://doi.org/10.31328/wy.v1i2.743

Nurcahyono, O. H., \& Astutik, D. (2018). Harmonisasi Masyarakat Adat Suku Tengger (Analisis Keberadaan Modal Sosial Pada Proses Harmonisasi Pada Masayarakat Adat Suku Tengger, Desa Tosari, Pasuruan, Jawa Timur). Dialektika Masyarakat: Jurnal Sosiologi, 2(1), 1-12.

ProFauna. (2019a). Aparat Bekuk Pedagang Satwa Langka di Kota Malang yang Jualan lewat Facebook. Retrieved July 7, 2019, from PROFAUNA website: http://profauna.net/id/content/aparat-bekuk-pedagang-satwa-langka-dikota-malang-yang-jualan-lewat-facebook

ProFauna. (2019b). Gerak Cepat Supporter ProFauna, Evakuasi Luntung Jawa di Probolinggo. Retrieved July 7, 2019, from PROFAUNA website: http://profauna.net/id/content/gerak-cepat-suporter-profauna-eva kuasilutung-jawa-di-probolinggo 
Salam, S. (2016). Perlindungan Hukum Masyarakat Hukum Adat Atas Hutan Adat. Jurnal Hukum Novelty. https://doi.org/10.26555/novelty.v7i2.a5468

Sawitri, R., \& Takandjandji, M. (2019). KONSERVASI DANAU RANU PANE DAN RANU REGULO DI TAMAN NASIONAL BROMO TENGGER SEMERU. Jurnal Penelitian Hutan Dan Konservasi Alam. https://doi.org/10.20886/jphka.2019.16.1.35-50

Suheriyanto, D. (2012). Keanekaragaman Fauna Tanah di Taman Nasional Bromo Tengger Semeru sebagi Bioindikator Tanah Bersulfur Tinggi. SAINSTIS, Vol.1(No. 2), 29-38. https://doi.org/10.18860/sains.v0i0.2307

Sukirno, S. (2018). Revitalisasi dan Aktualisasi Hukum Adat sebagai Sumber Hukum Pidana Positif. Diponegoro Private Law Review, 2(1).

Sulastriyono, S., \& Pradhani, S. I. (2018). Pemikiran Hukum Adat Djojodigoeno dan Relevansinya Kini. Mimbar Hukum - Fakultas Hukum Universitas Gadjah Mada. https://doi.org/10.22146/jmh.36956 